\title{
Chemical Composition and Antioxidant Activity of Essential Oils from Populations of Baccharis dracunculifolia DC. in Southern Brazil
}

Maíra Maciel Tomazzoli*

https://orcid.org/0000-0002-9946-2701

Wanderlei do Amaral ${ }^{2}$

https://orcid.org/0000-0003-0045-9615

Roger Raupp Cipriano ${ }^{1}$

https://orcid.org/0000-0002-3896-9074

Jéssica de Cássia Tomasi ${ }^{1}$

https://orcid.org/0000-0002-4333-3521

\author{
Erik Nunes Gomes ${ }^{3}$ \\ https://orcid.org/0000-0002-7999-070X
}

\author{
Aurea Portes Ferriani ${ }^{4}$ \\ https://orcid.org/0000-0002-2896-6427
}

Beatriz H. L. de Noronha Sales Maia ${ }^{4}$

https://orcid.org/0000-0001-5896-2892

Cicero Deschamps ${ }^{1}$

https://orcid.org/0000-0003-0786-0532

${ }^{1}$ Federal University of Paraná, Department of Crop Science and Crop Protection, Curitiba, Paraná, Brazil; ${ }^{2}$ Federal University of Paraná, Department of Chemical Engineering, Curitiba, Paraná, Brazil; ${ }^{3}$ Rutgers - The State University of New Jersey, Department of Plant Biology, New Brunswick, New Jersey, United States; ${ }^{4}$ Federal University of Paraná, Department of Chemistry, Curitiba, Paraná, Brazil.

Received: 2019.04.17; Accepted: 2020.11.15.

Editor-in-Chief: Paulo Vitor Farago

Associate Editor: Ana Cláudia Barana

*Correspondence: mairatomazzoli@gmail.com (M.M.T.).

\section{HIGHLIGHTS}

- Essential oils from populations of $B$. dracunculifolia were investigated.

- $\quad \beta$-pinene and $(E)$-nerolidol were the main compounds in B. dracunculifolia populations.

- The difference in the chemical profile of the essential oils is quantitative only.

- There is a negative correlation between the antioxidant activity and spathulenol.

Abstract: Baccharis dracunculifolia DC. is a Brazilian native plant, presenting wide chemical diversity and numerous pharmaceutical and industrial applications. This research assessed the yield, antioxidant activity and the chemical similarity of essential oils from 10 populations of $B$. dracunculifolia in the state of Paraná, southern Brazil. The extraction of the volatile compounds was carried out by hydrodistillation, the chemical composition was determined by GC/FID and GC/MS and the antioxidant activity by the DPPH method. The essential oil yield of wild $B$. dracunculifolia populations ranged from 0.14 to $0.87 \%$. The oils were predominantly composed of oxygenated sesquiterpenes (34.16 - 51.01\%), monoterpene hydrocarbons $(18.02-46.17 \%)$ and sesquiterpenes hydrocarbons $(9.60-17.70 \%)$. The major compounds found in all populations were $\beta$-pinene $(7.65-29.8 \%)$ and $(E)$-nerolidol $(9.11-21.68 \%)$. Essential oil solutions $(20 \%)$ from different populations presented antioxidant capacity ranging from 27.78 to $91.67 \%$. A negative correlation was found between the antioxidant activity and spathulenol $(r=-0.696)$. Multivariate analyses 
separated the populations into three groups: (1) low concentrations of $\alpha$-pinene $(2.02-2.06 \%)$, (2) high concentrations of $\alpha$-pinene $(4.17-4.61 \%)$ and $\beta$-pinene $(22.54-29.80 \%)$, and (3) intermediate concentrations of $\alpha$-pinene (2.38 - 3.31\%), $\beta$-pinene $(12.77-19.03 \%)$ and spathulenol $(6.02-9.06 \%)$.

Keywords: $\beta$-pinene; (E)-nerolidol; Alecrim-do-campo; DPPH; Medicinal Plant; Asteraceae; Chemotype; Secondary metabolites; Aromatic plants.

\section{INTRODUCTION}

Baccharis dracunculifolia DC. (Asteraceae) is a dioecious, perennial, 2-3 meters high woody shrub, usually propagated by seeds. The species is native to Brazil, with a wide distribution in the South, Southeast and Center-West regions of the country, especially in areas of Cerrado [1,2,3]. It also occurs naturally in other countries of South America such as Bolivia, Paraguay, Argentina, and Uruguay [1].

In addition to being widely known as the major botanical source of the so-called green propolis $[3,4]$ one of the main commercial uses of $B$. dracunculifolia relies on the aroma and medicinal properties of its essential oil. The volatile oils produced in the leaves of this species have been shown to have several biological properties such as antimicrobial [5], antibacterial [6], antiprotozoal [7], insecticide [8], anti-inflammatory [9] and acaridae [10] activities. Additionally, a previous study found that hydoethanolic extracts and essential oil of $B$. dracunculifolia leaves shows cytotoxic activity against HEp-2 cells (Human laryngeal epidermoid carcinoma) in vitro [11]. B. dracunculifolia oil is also widely used as a raw material in perfumery, representing a high value product for the fragrance industries [12].

The study of $B$. dracunculifolia populations from Southern Brazil, Uruguay and Bolivia has shown two distinct chemotypes, indicating large fluctuations in the quality of the essential oil due to genetic and environmental factors [13]. Despite the sesquiterpenes (E)-nerolidol (1.2 - 32.0\%) and spathulenol (6.0 $21.0 \%$ ) being frequently reported as major components of the volatile oil of $B$. dracunculifolia, other valuable compounds are also commonly identified, such as $\alpha$-pinene (1.01 - 5.8\%), $\beta$-pinene (1.93 - 43.4\%), myrcene $(0-2.8 \%)$, limonene $(1.15-13 \%),(E)-\beta$-caryophyllene $(0.4-6.5)$, germacrene $D(0.2-18.4 \%)$, bicyclogermacrene $(0.7-8.4 \%)$, $ү$-muurolene $(0.2-5.51 \%)$, $\delta$-cadinene $(0.1-3.64 \%)$, viridiflorol $(0.8-16.4 \%)$, caryophyllene oxide $(5.7-6.35 \%)$, (E)- $\beta$-oxyhemoglobin $(0.2-1.7 \%)$, epi- $\alpha$-muurolol $(0-2.9 \%)$ and $\alpha$ muurolol $(0.2-4.7 \%)[7,14,15]$.

The overall chemical composition and the presence/relative content of specific compounds are the main factors affecting the type of industry in which essential oils will be applied and, therefore, their final market value. Bioactive compounds extracted from plants can be used in several areas and important studies demonstrate their effectiveness as food natural preservatives [16,17]. Furthermore, studies indicate that, due to the antioxidant activity of $B$. dracunculifolia, the plant has great potential for the manufacture of various products in the areas of medicine, cosmetics and food [18]. One of the major compounds of $B$. dracunculifolia oil, (E)-nerolidol, for example, was recently approved in the United States by the Food and Drug Administration (FDA) as a flavoring agent in the food industry and is also known to inhibit the growth of Leishmania amazonenses [19]. Spathulenol, in turn, has demonstrated promising antibacterial [20] and moderate cytotoxic activities [21].

Such applications, coupled with new properties discovered as research progresses, tend to increase the use of $B$. dracunculifolia essential oil as a raw material for the pharmaceutical and flavor industries and, for this purpose, a constant offer of standardized plant material/essential oils will become increasingly important. Therefore, the understanding of chemical diversity in wild populations and, subsequently, the selection of highly productive accessions for domestication, cultivation and breeding are some of the initial steps to successfully satisfy the industrial demands [22].

Chemical diversity, including the content and chemical composition of essential oils, in plant species is ultimately determined by environmental (photoperiod, radiation, seasonality, nutrients availability, soil salinity, humidity and temperature) and genetic factors [23,24]. The genetic variability of plant populations, in turn, is mainly related to their size, geographic variations, reproductive habit and mechanism of seed dispersion [25]. For allogamous species as $B$. dracunculifolia, most of the genetic variation is found within the population [26]. In addition to genetic variations, geographic conditions can greatly affect the yield and chemical composition of essential oils. If the same genotype of a given aromatic plant is grown in different regions, there may be considerable differences in the chemical profile, reflecting the way plants adapt to ecological circumstances of each site [23].

Studies addressing essential oil yield and chemical variability in $B$. dracunculifolia populations are relatively scarce and limited to a few regions, more specifically the southeastern, (São Paulo state), and 
southern regions of Brazil, (Rio Grande do Sul state). Additional studies, in other regions of southern Brazil such as the state of Paraná, are important to understand how the secondary metabolism of the species behaves in different environmental conditions and also to identify potential accessions for domestication and breeding programs. In this regard, multivariate statistics tools can be used to detect patterns of similarity among the essential oils of different wild plant populations and may provide additional help for a better understanding of the main compounds that can be used as biomarkers of oil quality. In this sense, the aim of this study was to evaluate the content and chemical composition of essential oils from different populations of $B$. dracunculifolia, their chemical similarity and antioxidant activity.

\section{MATERIAL AND METHODS}

\section{Collection of plant material and climatic conditions}

Samples were collected in March 2016 from ten wild B. dracunculifolia populations in the State of Paraná, South of Brazil. All plant materials were collected in floral bud stage. Branches with leaves were collected from approximately twenty-five plants at each collection site. The climate of the region is classified as Cfb according to Köppen [27]. The precise location and specific climatic data of each population (average of March 2016) are described in Table 1.

\section{Essential oils isolation and chemical analysis}

Samples of $100 \mathrm{~g}$ of fresh leaves from each $B$. dracunculifolia population were submitted to hydrodistillation in Clevenger apparatus for 2 hours and 30 minutes. The oil yield was calculated in dry base, by volumetric moisture determination and the results were expressed as the percentage of leaves dry mass $(\%)$, considering the mean value of a triplicate for each population. The samples were stored in a freezer at $-5{ }^{\circ} \mathrm{C}$ until the chemical composition and antioxidant analyses were performed.

\section{Essential oils isolation and chemical analysis}

Samples of $100 \mathrm{~g}$ of fresh leaves from each $B$. dracunculifolia population were submitted to hydrodistillation in Clevenger apparatus for 2 hours and 30 minutes.

Table 1. Location of Baccharis dracunculifolia populations in the state of Paraná, Brazil, and climatic conditions of the collection sites (Average of march/2016).

\begin{tabular}{cccccccc}
\hline Populations & $\begin{array}{c}\text { Voucher } \\
\text { code }\end{array}$ & $\begin{array}{c}\text { Latitude } \\
(\mathrm{S})\end{array}$ & $\begin{array}{c}\text { Longitude } \\
(\mathrm{W})\end{array}$ & $\begin{array}{c}\text { Altitude } \\
(\mathrm{m})\end{array}$ & $\begin{array}{c}\text { Precipitation } \\
(\mathrm{mm})\end{array}$ & $\begin{array}{c}\text { Radiation } \\
\left(\mathrm{W} / \mathrm{m}^{2}\right)\end{array}$ & $\begin{array}{c}\text { Average } \\
\text { temperature } \\
\left({ }^{\circ} \mathrm{C}\right)\end{array}$ \\
\hline P1 & MBM-308.071 & $2^{\circ} 28^{\prime} 40^{\prime \prime}$ & $49^{\circ} 42^{\prime} 22^{\prime \prime}$ & 1055 & 12.8 & 1143 & 19.85 \\
P2 & MBM-326.212 & $2^{\circ} 28^{\prime} 13^{\prime \prime}$ & $49^{\circ} 43^{\prime} 42^{\prime \prime}$ & 1037 & 12.8 & 1143 & 19.85 \\
P3 & MBM-336.907 & $2^{\circ} 39^{\prime} 77^{\prime \prime}$ & $49^{\circ} 08^{\prime} 80^{\prime \prime}$ & 835 & 91.0 & 1065 & 20.24 \\
P4 & MBM-336.908 & $2^{\circ} 43^{\prime} 95^{\prime \prime}$ & $49^{\circ} 05^{\prime} 75^{\prime \prime}$ & 999 & 91.0 & 1065 & 20.24 \\
P5 & MBM-341.117 & $2^{\circ} 45^{\prime} 04^{\prime}$ & $49^{\circ} 01^{\prime} 91^{\prime \prime}$ & 886 & 91.0 & 1065 & 20.24 \\
P6 & MBM-343.530 & $2^{\circ} 32^{\prime} 19^{\prime \prime}$ & $49^{\circ} 04^{\prime} 35^{\prime \prime}$ & 908 & 92.2 & 1064 & 20.1 \\
P7 & MBM-348.144 & $2^{\circ} 30^{\prime} 64^{\prime \prime}$ & $49^{\circ} 02^{\prime} 06^{\prime \prime}$ & 916 & 92.2 & 1064 & 20.1 \\
P8 & MBM-350.603 & $2^{\circ} 30^{\prime} 30^{\prime}$ & $49^{\circ} 00^{\prime} 54^{\prime \prime}$ & 940 & 92.2 & 1064 & 20.1 \\
P9 & MBM-332.462 & $2^{\circ} 28^{\prime} 18^{\prime \prime}$ & $49^{\circ} 38^{\prime} 42^{\prime \prime}$ & 1194 & 92.0 & 1197 & 20.81 \\
P10 & MBM-334.697 & $2^{\circ} 19^{\prime} 80^{\prime \prime}$ & $49^{\circ} 48^{\prime} 35^{\prime \prime}$ & 1027 & 92.0 & 1197 & 20.81 \\
\hline
\end{tabular}

Source: Paraná Meteorological System (SIMEPAR). 2016. Voucher specimens were deposited in the Municipal Botanical Museum of Curitiba - MBM Herbarium, Paraná state, Brazil.

\section{Essential oils isolation and chemical analysis}

Samples of $100 \mathrm{~g}$ of fresh leaves from each $B$. dracunculifolia population were submitted to hydrodistillation in Clevenger apparatus for 2 hours and 30 minutes. The oil yield was calculated in dry base, by volumetric moisture determination and the results were expressed as the percentage of leaves dry mass $(\%)$, considering the mean value of a triplicate for each population. The samples were stored in a freezer at $-5{ }^{\circ} \mathrm{C}$ until the chemical composition and antioxidant analyses were performed. 
Essential oil chemical composition was assessed by gas chromatography (GC) coupled to flame ionization detector - FID (Agilent 7890A) and mass spectrometry detector - MS (Shimadzu-2010 Plus), both equipped with HP-5MS capillary column $(30 \mathrm{mx} 0.25 \mathrm{~mm} \times 0.25 \mu \mathrm{m}$ ). Hydrogen for GC/FID (flow $1.5 \mathrm{~mL} /$ $\mathrm{min}$ ) and helium for GC / MS (flow $1.0 \mathrm{~mL} / \mathrm{min}$ ) were used as the entrainment gases. The injector temperature remained constant throughout the analysis at $250^{\circ} \mathrm{C}$. The initial temperature of the oven was $60{ }^{\circ} \mathrm{C}$, rising to $240{ }^{\circ} \mathrm{C}$ at the rate of $3^{\circ} \mathrm{C} /$ minute.

A homologous series of alkanes (C7-C30) was used to identify the chemical constituents, aiming to calculate the linear retention index [28]. In addition to the retention indices, the mass spectrum of each compound was compared with data from the literature [29]. The quantification of the constituents was performed by dividing the peak area of each compound by the total area of identified compounds (\%) by GCFID.

\section{Antioxidant activity assay}

The antioxidant activity of $B$. dracunculifolia essential oils was determined by the radical and oxidizing agent 2, 2-Diphenyl-1-picrylhydrazyl (DPPH) method [30]. Initially, essential oil samples were diluted in methanol (P.A) at a concentration of $20 \%$. The control solution was prepared diluting $2.366 \mathrm{mg}$ of DPPH in $100 \mathrm{~mL}$ of methanol. Subsequently, a $0.1 \mathrm{~mL}$ aliquot of the essential oil/methanol solution was added to 3.9 $\mathrm{mL}$ of DPPH solution. After 30 minutes of incubation sheltered from light, the solution was subjected to UVVis spectrophotometry to determine absorbances $(\lambda=515 \mathrm{~nm})$. The results were expressed as percent inhibition, according to the formula:

$$
A A \%=100-\{[(\text { Abs. sample }- \text { Abs.control }) \times 100] \div \text { Abs. control }\}
$$

\section{Experimental design and statistical analyses}

Data were analyzed considering a completely randomized design, comparing the essential oil content and the antioxidant activity of 10 populations, each one with 3 repetitions. The results were submitted to the Bartlett test to verify the homogeneity of variances. The F-test of analysis of variance (ANOVA) was applied and, when significant, the data were submitted to the Scott-Knott test at $5 \%$ probability $(p<0.05)$, using the statistical software ASSISTAT® [31]. The mean values of antioxidant activity and chemical composition of the essential oils were analyzed by Pearson correlation analysis and multivariate statistics, using the main components (PCA) and hierarchical cluster analysis (HCA), using the statistical software R (v.3.1.1) [32]. In the cluster analysis, the Euclidean distance was used as mean of similarity and the non-weighted arithmetic mean (UPGMA) method was used for the hierarchical grouping process. The analyses were performed for the compounds with means higher than $3.0 \%$ in at least one of the populations.

\section{RESULTS AND DISCUSSION}

\section{Essential oil content (\%)}

There were significant differences in the essential oil yield among $B$. dracunculifolia wild populations, ranging from 0.14 to $0.87 \%$. The populations that presented the highest values were P2 $(0.82 \%)$ and P10 $(0.87 \%)$ (Figure 1$)$. In a previous study carried out with cultivated accessions of $B$. dracunculifolia from different Brazilian states, essential oil contents ranged from 0.31 to $0.70 \%$ [4]. Similarly, B. dracunculifolia plants treated with different doses of organic composting at the time of planting had oil contents ranging from 0.26 to $0.40 \%$ [14]. B. dracunculifolia's leaves from different stages of maturity produced different levels of essential oil, with yields of $1.2 \%$ for young leaves and $1.7 \%$ for a mixture of young and developed leaves [33]. Taken together, those studies illustrate the effect of genetic and environmental factors on oil content of this species. 


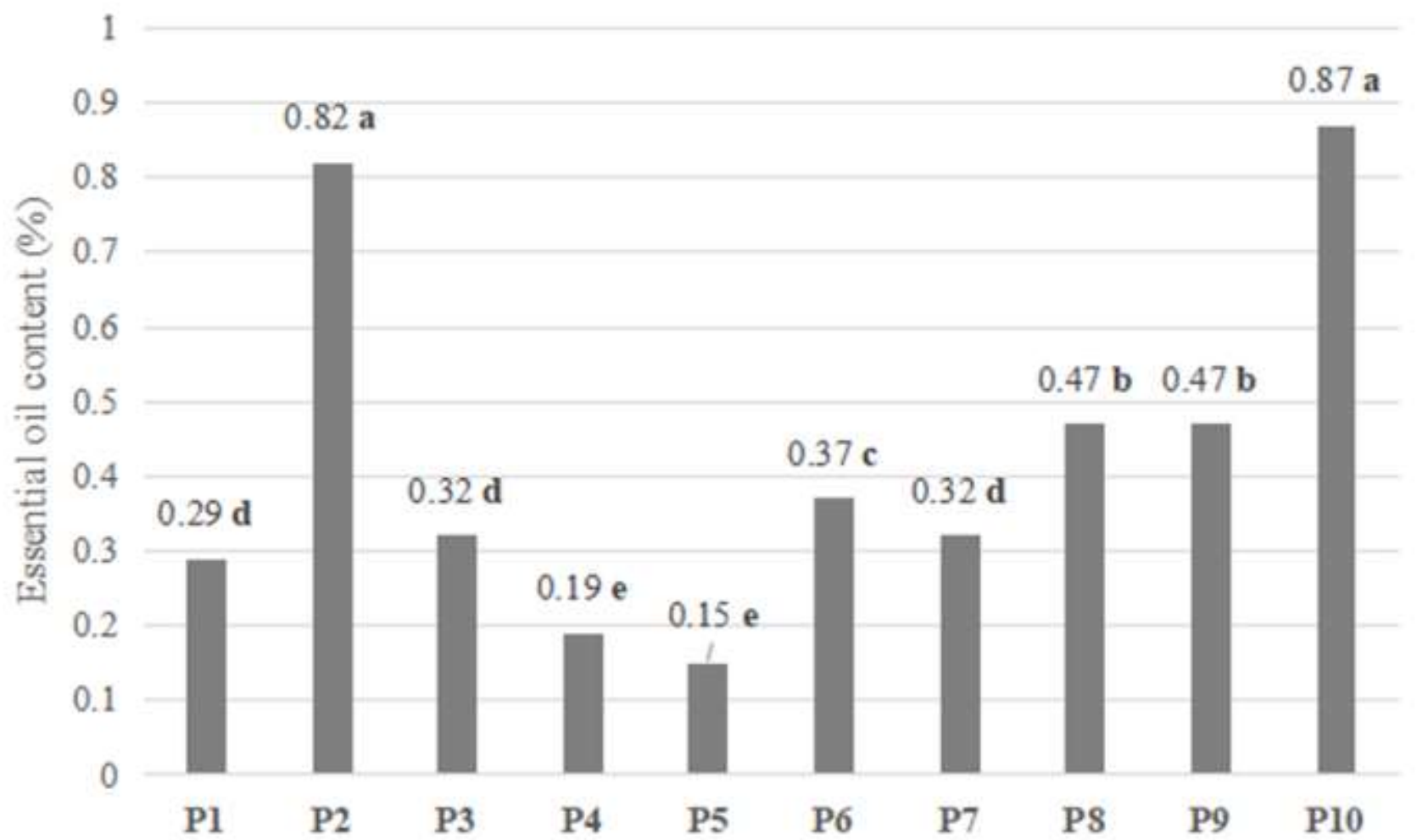

Figure 1. Essential oil content \% in fresh leaves of 10 populations $(P)$ of $B$. dracunculifolia from Paraná, Brazil. Means followed by the same letter do not differ by Scott-Knott test $(p<0.05)$.

However, in addition to genetic factors, environmental factors may also have influenced the production of essential oils in plants. Among the environmental conditions that can influence the content of essential oil is the solar radiation, where species that grow under high luminous intensities undergo a series of adaptations such as developing thicker leaves as a result of greater development of the palisade parenchyma and the vascular system. These structural modifications result in a greater capacity to capture solar radiation and, consequently, greater photosynthetic rates [34, 35]. Yet another modification plants use in order to overcome the excessive radiation is the development of trichomes. The essential oil of $B$. dracunculifolia is stored in pluricellular glandular trichomes, whose ecological function is thought to be increasing the light reflectance, avoiding excessive water loss and regulating the foliar temperature [34, 36]. In addition, different wavelengths of biologically active light can cause important effects in plant growth and responses to the environment and this may directly affect the synthesis of terpenes in the plant [37]. Some terpenes have well-established functions, such as isoprene, which protect leaves from UV-B heating [38]. The synthesis of terpenes in plants can occur by two pathways: the 2-C-methyl-D-erythritol 4-phosphate (MEP) in the plastids and the mevalonate (MVA) in the cytoplasm and terpene syntheses are the main enzymes responsible for the production of the various terpene compounds found $[39,40]$. In the plastids, the terpene synthase usually is reponsible for the formation of monoterpenes using geranyl diphosphate and in the cytoplasm this enzyme originates sesquiterpenes from farnesyl diphosphate [40]. The family of genes encoding terpene synthase enzymes have different members with high sequence homology. The size of terpene synthase's family with the promiscuity of each member contribute to the complexity of terpenoids produced in plants [37].

Water availability also affects the production of essential oils and several plant species present increases in their content under conditions of low precipitation [41]. The lower precipitation in the collection site of P2 may have contributed to the higher essential oil content of that population. One of the main damages caused by prolonged water stress is the production of reactive oxygen species (ROS), which will ultimately interfere in the structure of biomolecules and jeopardize overall plant physiology $[42,43]$. Therefore, the production of essential oils may represent a biochemical defense, as several terpenes present significant antioxidant activities [44,45].

However, possibly other environmental conditions besides those described in Table 2.1 combined with other factors, such as genetic factors, incidence of pests and diseases and different nutrient availability, may also have influenced this essential oil production. In response to adverse conditions plants may develop certain regulatory mechanisms through the induction of transcription factors. Thus, terpene production levels, for example, may vary according to the need for plant defense [46]. Such regulatory mechanisms, coupled 
with highly productive genotypes, might be explored by growers in order to induce higher oil productivity. Future studies should address such strategies to improve overall yield and quality of $B$. dracunculifolia essential oil.

\section{Essential oil chemical composition}

A total of 35 chemical constituents were identified in the essential oil from wild populations of $B$. dracunculifolia. The oils were predominantly composed of oxygenated sesquiterpenes (34.16 - 51.01\%), monoterpene hydrocarbons (18.02 - 46.17\%) and sesquiterpenes hydrocarbons (9.60 - 17.70\%). The major compounds found in all ten populations were $\beta$-pinene $(7.65-29.80 \%)$ and $(E)$-nerolidol $(9.11-21.68 \%)$ (Table 2).

The major compounds identified in the present study are similar to previous reports on essential oils of B. dracunculifolia collected/grown in the southern and southeastern regions of Brazil, for plants grown in the state of São Paulo, for example, (E)-nerolidol (33.51\%) and spathulenol (16.24\%) were identified as the major compounds [47]. (E)-nerolidol was also the major compound (22.3\%) in samples collected during winter in the state of Minas Gerais, followed by germacrene-D, limonene, and $\beta$-pinene [10]. For plants collected at a different region in the state of São Paulo, (E)-nerolidol was also the major compound $(25.84 \%)$ followed by spathulenol (13.14\%), germacrene-D (7.62\%), limonene $(6.93 \%)$ and $\beta$-pinene $(4.24 \%)$ [6]. For plants collected in the State of Santa Catarina, $\beta$-pinene $(9.94 \%)$ D-limonene $(9.59 \%), \beta$-nerolidol $(7.93 \%)$ and caryophyllene $(7.69 \%)$ were identified as major compounds [8]. 
Table 2. Mean and standard error of the compounds present in the essential oils \% (GC/FID) of ten populations (P) of B. dracunculifolia.

\begin{tabular}{|c|c|c|c|c|c|c|c|c|c|c|c|c|}
\hline Compounds & $I^{\text {lit }}$ & $\mathrm{IR}_{\mathrm{Ral}}$ & $\mathrm{P} 1$ & $\mathrm{P} 2$ & P3 & P4 & P5 & P6 & P7 & P8 & P9 & $\mathrm{P} 10$ \\
\hline 1- $\alpha$-tujene & 924 & 925 & - & $0.22 \pm 0.04$ & - & $0.71 \pm 0.00$ & - & $0.21 \pm 0.01$ & $0.22 \pm 0.03$ & - & - & 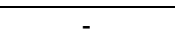 \\
\hline 2- $\alpha$-pinene & 932 & 932 & $2.06 \pm 0.03$ & $4.61 \pm 0.07$ & $3.06 \pm 0.01$ & $3.16 \pm 1.67$ & $2.02 \pm 0.26$ & $2.38 \pm 0.12$ & $2.76 \pm 0.45$ & $4.17 \pm 0.16$ & $3.12 \pm 0.04$ & $3.31 \pm 0.10$ \\
\hline 3- sabinene & 969 & 972 & - & & 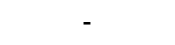 & $0.72 \pm 0.00$ & $0.18 \pm 0.05$ & 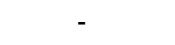 & & $0.37 \pm 0.00$ & & \pm 0.00 \\
\hline 4- $\beta$-pinene & 974 & 976 & $17.85 \pm 0.41$ & $29.8 \pm 4.20$ & $16.34 \pm 3.00$ & $15.14 \pm 3.86$ & $7.65 \pm 1.52$ & $19.03 \pm 0.38$ & $19.03 \pm 1.14$ & $22.54 \pm 1.15$ & $16.40 \pm 0.86$ & $12.77 \pm 0.99$ \\
\hline 5- myrcene & 988 & 990 & $0.89 \pm 0.39$ & $1.93 \pm 0.21$ & $2.21 \pm 0.02$ & $1.14 \pm 0.84$ & $0.87 \pm 0.17$ & $1.81 \pm 0.01$ & $2.13 \pm 0.04$ & $1.86 \pm 0.12$ & $1.29 \pm 0.46$ & $1.62 \pm 0.27$ \\
\hline 6- limonene & 1024 & 1026 & $2.60 \pm 0.07$ & $8.46 \pm 1.19$ & $11.66 \pm 0.19$ & $9.61 \pm 4.96$ & $6.9 \pm 1.87$ & $11.24 \pm 1.10$ & $12.04 \pm 0.04$ & $15.13 \pm 1.14$ & $5.51 \pm 0.01$ & $12.58 \pm 2.83$ \\
\hline 7- (E)- $\beta$-ocimene & 1044 & 1045 & $1.17 \pm 0.47$ & $1.69 \pm 0.21$ & $1.03 \pm 0.14$ & $0.69 \pm 0.46$ & $0.40 \pm 0.06$ & $0.89 \pm 0.04$ & $1.53 \pm 0.03$ & $1.14 \pm 0.06$ & $0.75 \pm 0.21$ & $0.9 \pm 0.13$ \\
\hline 8- terpinen-4-ol & 1174 & 1174 & $0.27 \pm 0.01$ & $0.30 \pm 0.03$ & $0.38 \pm 0.01$ & $0.32 \pm 0.14$ & $0.14 \pm 0.01$ & $0.30 \pm 0.00$ & $0.22 \pm 0.04$ & $0.26 \pm 0.03$ & $0.26 \pm 0.04$ & $0.27 \pm 0.04$ \\
\hline 9- $\alpha$-terpineol & 1186 & 1188 & $0.49 \pm 0.14$ & $0.47 \pm 0.06$ & $0.45 \pm 0.02$ & $0.44 \pm 0.05$ & $0.24 \pm 0.04$ & $0.47 \pm 0.08$ & $0.28 \pm 0.08$ & $0.67 \pm 0.05$ & $0.45 \pm 0.04$ & $0.63 \pm 0.09$ \\
\hline emene & 1335 & 1333 & $0.17 \pm 0.04$ & $0.13 \pm 0.00$ & - & $0.16 \pm 0.00$ & $0.15 \pm 0.03$ & $0.23 \pm 0.00$ & $0.70 \pm 0.09$ & - & $0.12 \pm 0.00$ & - \\
\hline lemene & 1389 & 1388 & $0.37 \pm 0.07$ & $0.25 \pm 0.04$ & $6 \pm 0$ & $0.33 \pm 0.07$ & $0.36 \pm 0.05$ & $0.30 \pm 0.12$ & - & - & $34 \pm 0.03$ & $15 \pm 0.01$ \\
\hline$\beta$-cary & 1417 & 1413 & $2.75 \pm 0.51$ & $0.99 \pm 0.11$ & $1.57 \pm 0.11$ & $1.77 \pm 0.55$ & $2.10 \pm 0.33$ & $1.24 \pm 0.09$ & $2.89 \pm 0.2$ & $1.31 \pm 0$ & $0 \pm 0.23$ & $.06 \pm 0.03$ \\
\hline 13- & 1439 & 1432 & $0.36 \pm 0.08$ & $0.19 \pm 0.02$ & $0.27 \pm 0.03$ & $0.29 \pm 0.01$ & $0.35 \pm 0.01$ & $0.29 \pm 0.00$ & $0.29 \pm 0.12$ & $8 \pm 0$ & $5 \pm 0.04$ & $0.47 \pm 0.02$ \\
\hline reuva & 1462 & 1456 & $0.57 \pm 0.09$ & $0.32 \pm 0.02$ & $0.56 \pm 0.11$ & $0.64 \pm 0.02$ & $0.84 \pm 0.13$ & $0.60 \pm 0.16$ & $0.38 \pm 0.17$ & $0.54 \pm 0$ & $.67 \pm 0.05$ & $0.83 \pm 0.05$ \\
\hline $15-$ & 171 & 1468 & $0.20 \pm 0.02$ & $0.12 \pm 0.01$ & - & \pm 0.00 & $0.15 \pm 0.00$ & $0.19 \pm 0.07$ & $0.16 \pm 0.04$ & $4 \pm 0$ & $5 \pm 0.01$ & $0.14 \pm 0.01$ \\
\hline macren & 1484 & 1474 & $3.46 \pm 0.64$ & $1.84 \pm 0.26$ & $2.29 \pm 0.68$ & $2.65 \pm 0.66$ & $3.39 \pm 0.23$ & $3.02 \pm 1.11$ & $2.38 \pm 0.97$ & $2.18 \pm 0.22$ & $5 \pm 0.24$ & $1.87 \pm 0.07$ \\
\hline yclogerr & 1500 & 1490 & $6.36 \pm 1.25$ & $3.82 \pm 0.45$ & $3.71 \pm 1.0$ & $4.39 \pm 1.07$ & $5.59 \pm 0.97$ & $4.84 \pm 1.71$ & $5.38 \pm 0.81$ & $3.75 \pm 0$ & $3.83 \pm 0.46$ & $3.54 \pm 0.10$ \\
\hline $18-$ & 00 & 1495 & $0.42 \pm 0.07$ & $0.20 \pm 0.06$ & - & $0.33 \pm 0.09$ & $0.38 \pm 0$ & $0.37 \pm 0.14$ & $0.28 \pm 0.06$ & $1 \pm 0$ & $3 \pm 0$ & $0.21 \pm 0.03$ \\
\hline $19-$ & 1513 & 1508 & $0.57 \pm 0.09$ & $0.36 \pm 0.08$ & - & $2 \pm 0.13$ & $2 \pm 0$ & $0.50 \pm 0.17$ & $0.51 \pm 0.08$ & $3 \pm 0$ & $5 \pm$ & $.32 \pm 0.04$ \\
\hline $20-$ & 1522 & 1519 & $2.47 \pm 0.39$ & $1.38 \pm 0.19$ & $1.62 \pm 0$. & $8 \pm 0.05$ & $2.07 \pm 0.13$ & $1.60 \pm 0.02$ & $1.43 \pm 0.10$ & $1 \pm 0$ & $77 \pm c$ & $1.37 \pm 0.15$ \\
\hline $21-$ & 1561 & 1564 & $4.93 \pm 1.78$ & $13.2 \pm 1.71$ & $19.35 \pm 4.49$ & $3 \pm 3.64$ & $20.71 \pm 1.3$ & $13.38 \pm 2.5$ & $13.98 \pm 2.47$ & \pm 0 & $22.6 \pm 3.47$ & $21.68 \pm 3.35$ \\
\hline $22-s$ & 1577 & 1570 & $7.02 \pm 0.57$ & $6.7 \pm 0.63$ & $6.68 \pm 1.25$ & $8.23 \pm 1.68$ & $8.49 \pm 0.13$ & $7.52 \pm 1.21$ & $9.6 \pm 1.86$ & $7.69 \pm 0$ & $6.02 \pm 0.97$ & $6.91 \pm 0.42$ \\
\hline Sopaen- & 1590 & 1576 & $4.71 \pm 0.72$ & $2.79 \pm 0.28$ & $3.46 \pm 0.91$ & $3.88 \pm 0.93$ & $4.13 \pm 0.11$ & $3.42 \pm 0.76$ & $3.78 \pm 0.96$ & $3.22 \pm 0$ & $3.22 \pm 0.53$ & $4.22 \pm 0.20$ \\
\hline diflorol & 1592 & 1583 & $1.13 \pm 0.27$ & $1.65 \pm 0.29$ & $2.70 \pm 0.31$ & $1.96 \pm 0.10$ & $2.10 \pm 0.51$ & $1.84 \pm 0.15$ & $2.23 \pm 0.18$ & $1.78 \pm 0$ & $2.24 \pm 0.29$ & $1.02 \pm 0.03$ \\
\hline beban-11-ol & 1595 & 1586 & $0.28 \pm 0.07$ & $0.14 \pm 0.02$ & - & $0.31 \pm 0.00$ & $0.25 \pm 0.02$ & $0.22 \pm 0.08$ & - & $0.16 \pm 0$ & $0.18 \pm 0.04$ & $0.21 \pm 0.01$ \\
\hline $26-1$ & 1602 & 1594 & $2.18 \pm 0.37$ & $1.72 \pm 0.17$ & $1.55 \pm 0$. & $2.19 \pm 0.20$ & $2.55 \pm 0.1$ & $1.44 \pm 0.06$ & $1.59 \pm 0.23$ & $7 \pm 0$ & $.11 \pm 0$ & $2.01 \pm 0.10$ \\
\hline $27-\beta$ & 1607 & 1604 & $0.28 \pm 0$ & $0.21 \pm 0.03$ & $7 \pm 0$ & \pm 0.11 & \pm 0 & $0.29 \pm 0.07$ & $0.26 \pm 0.08$ & $8 \pm 0$ & $0.27 \pm c$ & $0.25 \pm 0.02$ \\
\hline $28-$ & 18 & 1615 & $.25 \pm 0$ & $0.16 \pm 0.01$ & $7 \pm 0$ & \pm 0.00 & \pm 0 & $0.19 \pm 0.06$ & $0.33 \pm 0.00$ & $5 \pm 0$ & \pm & $0.26 \pm 0.01$ \\
\hline $29-$ & 1627 & 1621 & $.95 \pm 0.14$ & $0.53 \pm 0.05$ & $0.27 \pm 0.0$ & $71 \pm 0.02$ & $0.82 \pm 0.08$ & $0.46 \pm 0.10$ & $0.51 \pm 0.12$ & $0.47 \pm 0$ & $0.76 \pm 0$ & $0.42 \pm 0.03$ \\
\hline $30-$ & 1640 & 1635 & $3.13 \pm 0.56$ & $1.91 \pm 0.27$ & $1.67 \pm 0.0$ & $2.33 \pm 0.71$ & $2.87 \pm 0.12$ & $1.66 \pm 0.07$ & $1.26 \pm 0.14$ & $2.00 \pm 0$ & $2.17 \pm 0.22$ & $1.89 \pm 0.23$ \\
\hline $31-$ & 1644 & 1640 & $0.94 \pm 0.17$ & $0.59 \pm 0.09$ & $0.66 \pm 0.20$ & $2.33 \pm 0.71$ & $1.11 \pm 0.17$ & $0.59 \pm 0.16$ & $0.54 \pm 0.17$ & $0.62 \pm 0.04$ & $0.75 \pm 0.11$ & $0.56 \pm 0.05$ \\
\hline 32- $\alpha$-cadinol & 1652 & 1647 & $3.85 \pm 0.03$ & $2.56 \pm 0.59$ & $2.79 \pm 0.03$ & $2.95 \pm 0.38$ & $3.93 \pm 0.16$ & $3.00 \pm 0.09$ & $2.07 \pm 0.53$ & $2.75 \pm 0.19$ & $2.66 \pm 0.36$ & $2.21 \pm 0.26$ \\
\hline $33-g$ & 1685 & 1678 & $1.87 \pm 0.38$ & $1.37 \pm 0.31$ & $1.14 \pm 0.18$ & $1.91 \pm 0.1$ & $2.51 \pm 0.35$ & $1.32 \pm 0.10$ & $1.10 \pm 0.30$ & $1.99 \pm 0.15$ & $2.25 \pm 0.46$ & $1.32 \pm 0.17$ \\
\hline icyclogermacrenal & 1733 & 1724 & $0.34 \pm 0.07$ & $0.37 \pm 0.07$ & $0.41 \pm 0.12$ & $0.48 \pm 0.19$ & $0.60 \pm 0.05$ & $0.43 \pm 0.13$ & $0.26 \pm 0.01$ & $0.50 \pm 0.04$ & $0.42 \pm 0.10$ & $0.36 \pm 0.03$ \\
\hline 35- khusimol & 1741 & 1733 & $0.27 \pm 0.06$ & $0.26 \pm 0.07$ & $0.28 \pm 0.10$ & $0.33 \pm 0.16$ & $0.38 \pm 0.00$ & $0.29 \pm 0.10$ & $0.32 \pm 0.14$ & $0.37 \pm 0.04$ & $0.26 \pm 0.08$ & $0.25 \pm 0.04$ \\
\hline Mono & & & 24.57 & 46.71 & 34.30 & 31.17 & 18.02 & 35.56 & 37.85 & 45.21 & 27.07 & 31.39 \\
\hline Oxyg & & & 0.76 & 0.77 & 0.83 & 0.76 & 0.38 & 0.77 & 0.50 & 0.93 & 0.71 & 0.90 \\
\hline & & & 17.70 & 9.60 & 10.28 & 13.06 & 15.90 & 13.18 & 14.40 & 10.25 & 13.91 & 10.96 \\
\hline & & & 42.13 & 34.16 & 41.50 & 46.54 & 51.01 & 36.05 & 37.83 & 33.16 & 46.11 & 43.57 \\
\hline Ident & & & 84.45 & 91.24 & 86.91 & 91.53 & 85.31 & 85.56 & 90.58 & 89.55 & 87.80 & 86.82 \\
\hline
\end{tabular}

Rl lit: retention index of the literature Adams[29]. Rlcal: calculated retention index. - trace element $<0.1 \%$. 
In a previous study conducted with leaves in different stages of development, a similar chemical profile was found for all samples, with slight quantitative variations. The main compounds detected in the essential oil were: germacrene D, 12.99 - 8.79\%; trans-caryophyllene, $6.81-7.71 \%$; nerolidol, $5.73-6.50 \%$; and spathulenol, $3.81-4.55 \%$ 33. Analysis of the essential oil of Baccharis milleflora species showed similar compounds to $B$. dracunculifolia: trans-caryophyllene (7.65 - 13.41\%), germacrene-D (6.83 - $11.18 \%)$, bicyclogermacrene $(9.99$ - 12.89\%) were the major compounds, besides presenting antimicrobial activity against Staphylococcus aureus [48]. As previously mentioned, the knowledge of essential oils chemical composition is a fundamental aspect of their marketing and, therefore, is one of the most important selection criteria for exploitation of wild aromatic plant populations and/or for breeding and domestication programs.

In order to better understand the chemical variability of the studied populations of $B$. dracunculifolia, principal component analysis - PCA (Figure 2) and cluster analysis (Figure 3) were performed. These analyses considered only the chemical constituents with averages higher than $3.0 \%$ in at least one of the populations (Table 2). In the PCA analysis, the first three main components explained $86.10 \%$ of the sample variability. The compounds that were most significant to order the populations were spathulenol $(0.6298), \beta$ pinene (0.5306) and a-pinene (0.4332) (Table 3).

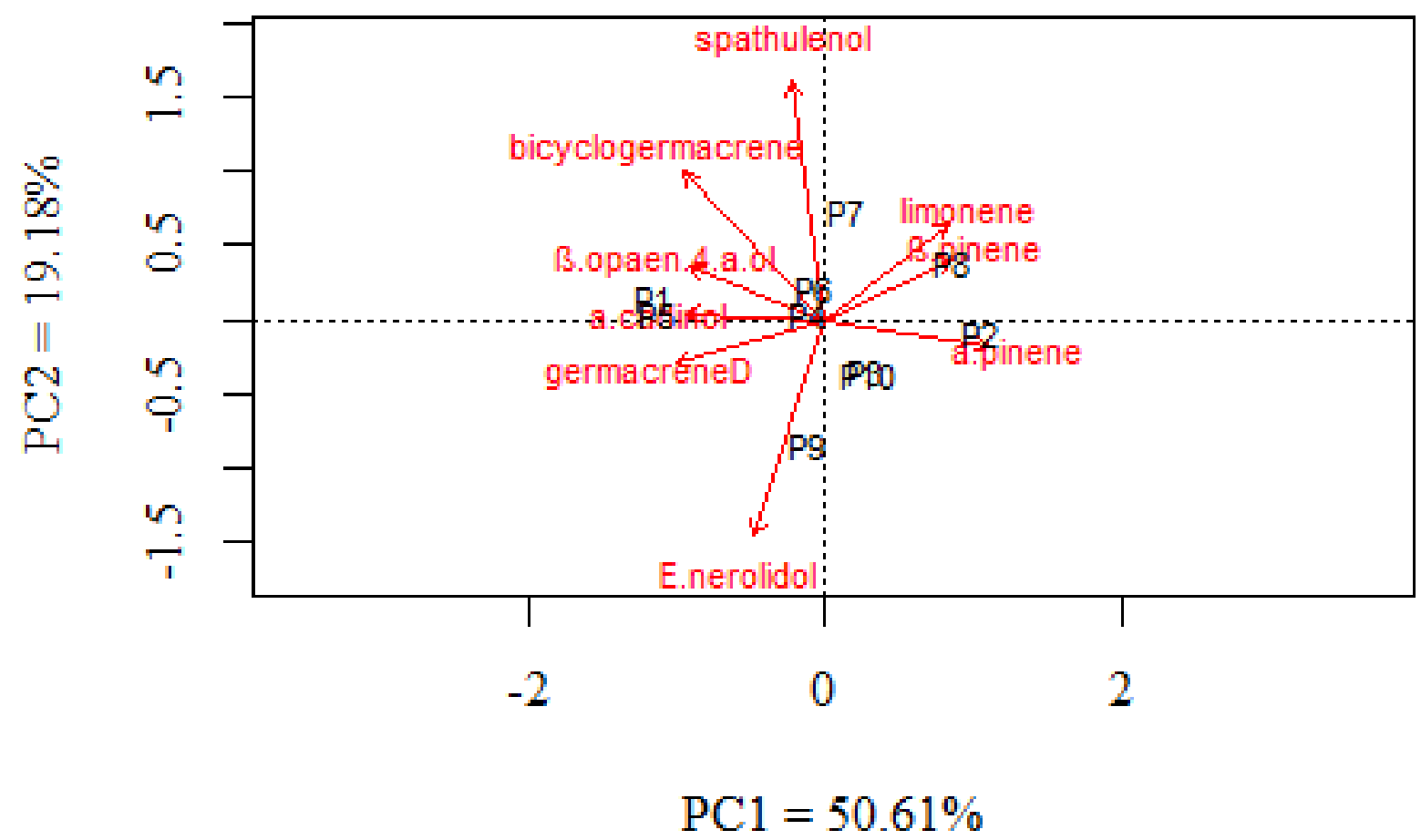

Figure 2. Principal component analysis (PCA) of the essential oil composition in populations $(\mathrm{P})$ of $B$. dracunculifolia, Paraná, Brazil (March, 2016).

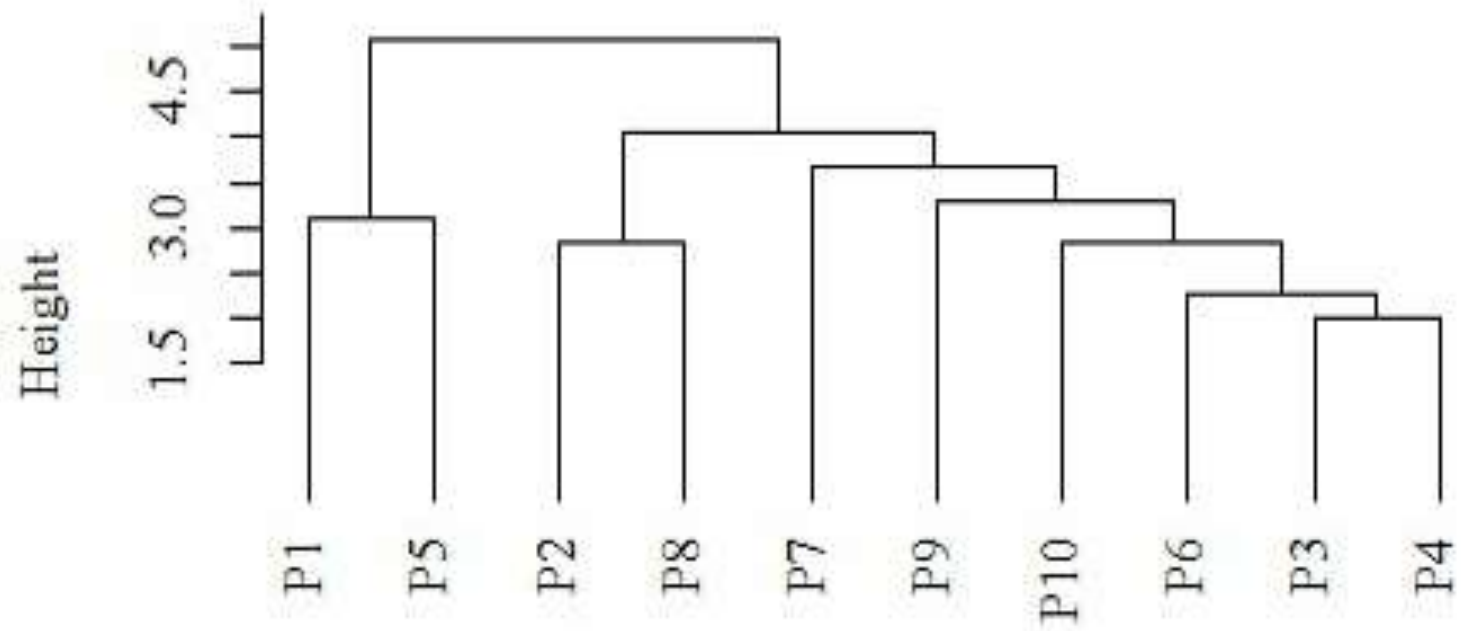

Figure 3. Cluster hierarchical analysis (UPGMA method - 75\% cophenetic correlation) of the essential oil composition in populations (P) of $B$. dracunculifolia, Paraná, Brazil (March, 2016). 
The populations were separated into three groups. The first group consisted of populations P1 and P5, characterized by low concentrations of $\alpha$-pinene $(2.02-2.06 \%)$. The second group included populations P2 and P8, with high levels of $\alpha$-pinene $(4.17-4.61 \%)$ and $\beta$-pinene $(22.54-29.80 \%)$. Finally, the third group was formed by the other populations, characterized by intermediate concentrations of $\alpha$-pinene $(2.38-3.31 \%), \beta$ pinene (12.77-19.03\%) and spathulenol (6.02 -9.06\%). The differences in the essential oils in each group, however, are mainly quantitative and do not seem to indicate the presence of different chemotypes.

Table 3. Principal components (PC), variance (eigenvalue) and cumulative variance (\%) obtained from the chemical composition $(\geq 3.0 \%)$ and the antioxidant/DPPH analysis of the essential oils of $B$. dracunculifolia from ten populations collected in the state of Paraná, Brazil.

\begin{tabular}{|c|c|c|c|}
\hline \multirow{2}{*}{ Composition } & \multicolumn{3}{|c|}{ Main component } \\
\hline & PC1 & PC2 & PC3 \\
\hline a-pinene & 0.4332 & -0.0669 & 0.1265 \\
\hline$\beta$-pinene & 0.3310 & 0.1603 & 0.5306 \\
\hline Limonene & 0.3220 & 0.2527 & -0.4388 \\
\hline Germacrene D & -0.3942 & -0.1144 & 0.2433 \\
\hline bicyclogermacrene & -0.374 & 0.3921 & 0.1880 \\
\hline (E)-nerolidol & -0.1869 & -0.5681 & -0.3871 \\
\hline spathulenol & -0.0862 & 0.6298 & -0.3202 \\
\hline$\beta$-opaen-4- $\alpha$-ol & -0.3564 & 0.1385 & -0.2562 \\
\hline a-cadinol & -0.3657 & 0.0180 & 0.3116 \\
\hline Variance (eigenvalue) & 4.555 & 1.727 & 1.467 \\
\hline Cumulative variance (\%) & 50.61 & 69.80 & 86.10 \\
\hline
\end{tabular}

In a previous study, multivariate tools were also applied to understand the chemical diversity of volatile compounds in 9 populations of $B$. dracunculifolia. Different from the observed in the present study, however, the analysis revealed the existence of two chemotypes: one characterized by the predominance of alcohols derived from aromadendrene (spathulenol, globulol and viridiflorol) and the other with the predominance of cadinane-derived compounds ( $\gamma$-cadinene, $\delta$-cadinene, $T$-cadinol and $\alpha$-cadinol) [13].

For Baccharis trimera samples collected in different states of southern Brazil, the PCA analysis separated the samples into two distinct groups: volatile samples extracted from the cladodes and from shoots or inflorescences. Nevertheless, similarly to the results here presented, the authors suggested that the same chemotype of $B$. trimera occurs in the three southern states of Brazil and the strongest factor to discriminate the oils in that species seems to be the plant organ from where it is collected [49]. For the same species, environmental conditions have been shown to exert significant influence on essential oil biosynthesis [50].

Previous studies have also shown that the chemical composition of $B$. dracunculifolia volatile oils can be greatly influenced by external factors, including the altitude and latitude of a particular site [13]. However, populations from different sites, under the influence of the different climatic conditions were separated into the same group according to their chemical composition, such as I) P1 and P5; II) P2 and P8 (Figure 3). This reinforces that other factors besides those evaluated in this study, e.g. genetic and climatic, may have influenced the terpenic composition of the plant.

\section{Antioxidant activity}

The essential oils from different $B$. dracunculifolia populations presented antioxidant activities ranged from 27.78 to $91.67 \%$. The highest free radical-scavenging capacity was found in population P3 (Figure 4). Pearson's correlation analysis showed a significant negative correlation between the antioxidant activity and the compound spathulenol $(r=-0.696)$ in the oils (Table 4). 


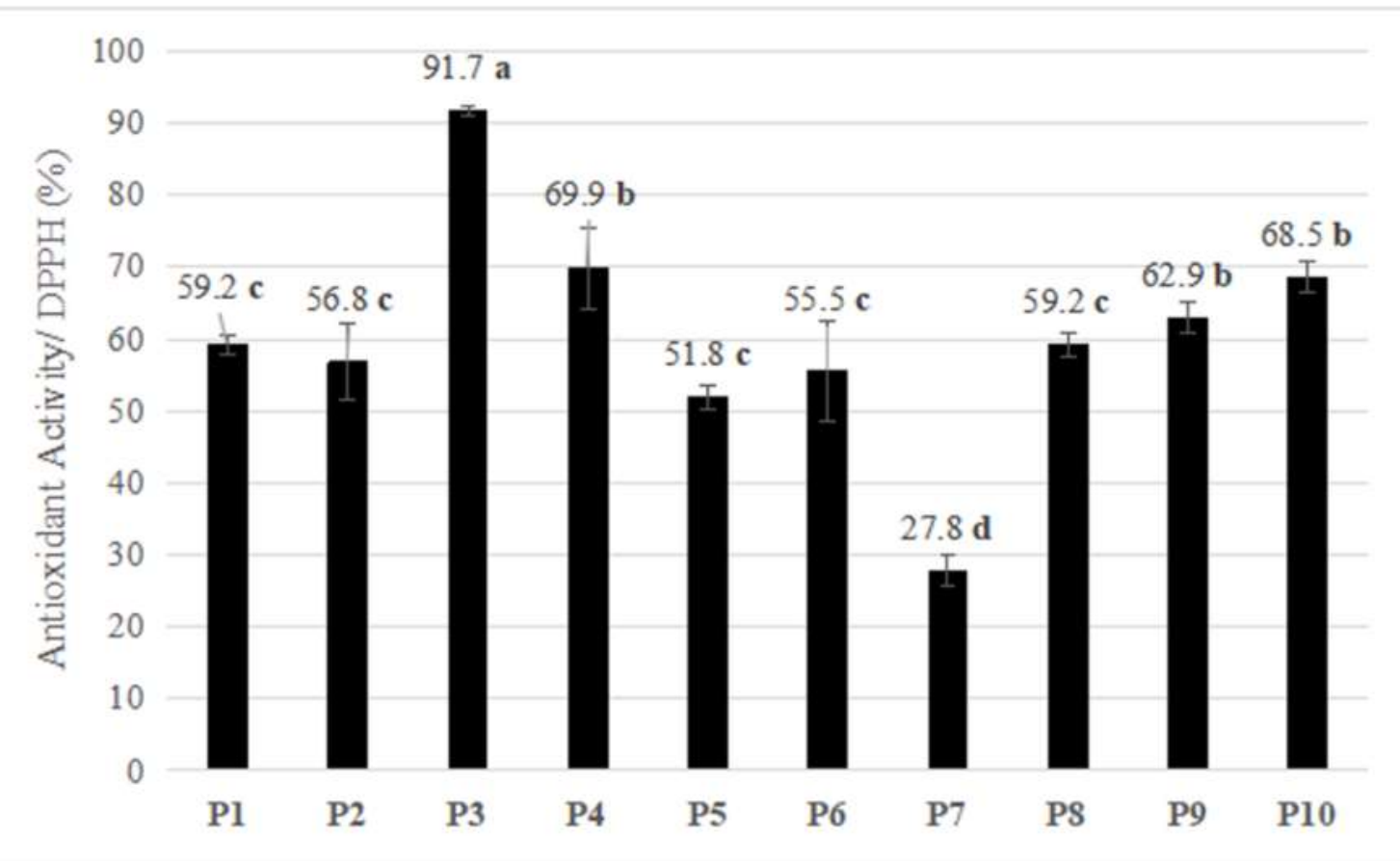

Figure 4. Means and standard errors of the antioxidant activities (DPPH method) of essential oils of ten $B$. dracunculifolia populations (P) from the state of Paraná, Brazil (March, 2016). Means followed by the same letter do not differ by Scott-Knott test $(p<0.05)$.

Table 4. Pearson correlation coefficients between $B$. dracunculifolia essential oil contituents, antioxidant activity (DPPH) and climatic factors: altitude, radiation ( $\mathrm{rad})$, temperature (temp) and precipitation (prec).

\begin{tabular}{|c|c|c|c|c|c|c|c|c|c|c|}
\hline Composition & $\mathrm{DPPH}$ & $p$-value & Altitute & $p$-value & Rad & $p$-value & $\operatorname{Temp}\left({ }^{\circ} \mathrm{C}\right)$ & $p$-value & Prec & $p$-value \\
\hline$\beta$-pinene & -0.24 & 0.68 & 0.04 & 0.64 & 0.04 & 0.62 & -0.53 & 0.93 & -0.54 & 0.1 \\
\hline$\alpha$-pinene & 0.01 & 0.73 & 0.17 & 0.77 & 0.17 & 0.62 & -0.03 & 0.11 & -0.15 & 0.66 \\
\hline limonene & 0.03 & 0.92 & -0.40 & 0.11 & -0.40 & 0.24 & 0.10 & 0.77 & 0.57 & 0.08 \\
\hline spathulenol & $-0.69^{*}$ & 0.03 & 0.53 & 0.11 & $-0.67^{*}$ & 0.03 & -0.31 & 0.37 & 0.31 & 0.38 \\
\hline$\beta$-opaen-4- $\alpha$-ol & -0.01 & 0.86 & 0.05 & 0.88 & 0.05 & 0.87 & 0.037 & 0.91 & -0.05 & 0.87 \\
\hline bicyclogermacrene & -0.50 & 0.12 & -0.14 & 0.69 & 0.26 & 0.46 & -0.49 & 0.14 & -0.30 & 0.38 \\
\hline$\alpha$-cadinol & 0.09 & 0.78 & 0.12 & 0.77 & 0.20 & 0.56 & -0.35 & 0.31 & -0.29 & 0.41 \\
\hline germacrene D & -0.11 & 0.71 & 0.25 & 0.48 & 0.01 & 0.95 & 0.047 & 0.89 & 0.01 & 0.99 \\
\hline (E)-nerolidol & 0.47 & 0.267 & 0.27 & 0.43 & 0.45 & 0.19 & $0.76^{*}$ & 0.01 & 0.30 & 0.38 \\
\hline
\end{tabular}

${ }^{*}$ Significant at $5 \%$ probability $(p<0.05)$.

Antioxidant compounds are widely studied because of their ability to retard or inhibit reactions that cause ROS damage to living cells, therefore protecting biological systems and functionality of important biomolecules such as lipids, proteins and DNA [51]. Studies on biological activities of Baccharis species have shown a wide array of possible applications, mainly related to the allelopathic, antimicrobial, cytotoxic, antiinflammatory and antioxidant effects [12].

Scavenging of reactive oxygen species, such as superoxide, hydrogen peroxide, hydroxyl radical, among others, is possible by the use of enzymatic (e.g. superoxide dismutase, catalase, ascorbate peroxidase, among others) and non-enzymatic (i.e. antioxidant compounds) mechanisms [51,52]. Neto and coauthors [53] showed a significant increase in the activity of superoxide dismutase after (E)-nerolidol treatment in mice, inferring the antioxidant-stimulant effect of this sesquiterpene.

Significant antioxidant activities have been previously reported for the major components here identified in $B$. dracunculifolia essential oils (i.e: $\beta$-pinene, (E)-nerolidol and limonene) [45,54,55], suggesting the possibility of using such compounds and the oils from the different populations in pharmaceutical and cosmetic formulations. On other hand, low antioxidant activity was reported for the essential oils of $B$. dracunculifolia and other plant species by Miranda [56]. This may occur because some compounds do not have hydrogen atoms in the allylic and / or benzyl positions. Previous studies conducted on Baccharis species which produced $\beta$-pinene as major compound or in high contents showed low free radical capture by DPPH $[57,58]$. Therefore, such compound is probably not the main responsible for the antioxidant activity of the essential oils of various plant species. 
Although it was not possible to identify a positive correlation of the antioxidant activity (Table 4) with the grouping of the populations or with any specific compound in the oils, the antioxidant potential found in some samples can be a result of synergistic effects of two or more compounds. Accordingly, studies with essential oil of Calophyllum cardiopetalum leaves, for example, have not correlated isolated compounds with antioxidant activity. However, when $\beta$-caryophyllene was combined with phenolic compounds, an evident increase in antioxidant capacity by means of synergistic effects was observed [59]. Therefore, the correlation between compounds that have potential biological activities is a complex feature, as the synergistic effect between metabolites can have major effects on these activities [60].

Interestingly, spathulenol showed significant negative correlation with both antioxidant activity and radiation levels (Table 4). Such phenomena may suggest that other compounds or group of compounds, with stronger antioxidant activity, are accumulated in detriment of spathulenol to alleviate oxidative stress generated by radiation in $B$. dracunculifolia. Similarly, spathulenol contents in sage (Salvia officinalis L.) fruits are reported to decrease under $\mathrm{NaCl}$ stress [61], a condition that is also known to produce oxidative damages in plant cells. $(E)$-nerolidol, on the other hand, showed positive correlation with temperature, suggesting that it may play some role on alleviation of heat stress on $B$. dracunculifolia. Similarly, heat stressed chamomile plants were reported to produce higher amounts of nerolidol [62]. Another possibility is the fact that higher temperatures, up to $30^{\circ} \mathrm{C}$, increase herbivory [63], and nerolidol, as a well studied inducible herbivoredefense mechanism [64], may be accumulated in response to such environmental conditions.

The results here presented highlight one of the many natural products biosynthesized by $B$. dracunculifolia. The knowledge of phytochemical diversity and biological activities are crucial steps for sustainable exploitation and must be followed by agronomic studies in order to assure the availability of raw material for current and future uses of this species as the understanding of its biological properties progresses.

\section{CONCLUSION}

This study shows quantitative differences on overall content and relative abundance of specific compounds of essential oils from $B$. dracunculifolia populations from southern Brazil. The major components of the studied populations are $\beta$-pinene and $(E)$-nerolidol. The antioxidant capacity of oils from different populations also presents variations, ranging from 27.78 to $91.67 \%$, and there is a negative correlation between this activity and spathulenol. The multivariate analyses separate the populations into three groups: (1) populations with low concentration of $\alpha$-pinene, (2) populations with high concentrations of $\alpha$-pinene and $\beta$-pinene and (3) populations with intermediate concentrations of $\alpha$-pinene, $\beta$-pinene and spathulenol.

Funding: This authors researchers was funded by from CAPES (Coordination for the Improvement of Higher Education Personnel) to the first, fourth (Finance code 001) and fifth authors (DOC_PLENO/ proc. no 88881.129327/2016-01). Acknowledgments: The authors are also grateful to the Environmental Institute of Paraná (IAP) for granting the licenses (09.19) for collecting and transporting plant material and for the Meteorological System of Paraná - SIMEPAR for granting meteorological data.

Conflicts of Interest: The authors declare no conflict of interest. The funders had no role in the design of the study; in the collection, analyses, or interpretation of data; in the writing of the manuscript, or in the decision to publish the results.

\section{REFERENCES}

1. Boldt PE. Baccharis (Asteraceae). A Review of its taxonomy, phytochemistry, ecology, economic status, natural enemies and potential for its biological control in the United States. 1st ed. USDA: Agricultural Research Service Grassland; 1989.

2. Barroso GM, Bueno OL. Flora llustrada Catarinense Plantas Compostas-Subtribo: Baccharidinae. 1st ed. Itajaí: Herbário Barbosa Rodrigues (HBS); 2002.

3. Park YK, Paredes-Guzman JF, Aguiar CL, Alencar SM, Fujiwara FY. Chemical constituents in Baccharis dracunculifolia as the main botanical origin of southeastern brazilian propolis. J Agric Food Chem. 2004 Mar;52:1100-3. doi:10.1021/jf021060m.

4. Sforcin JM, Filho JPB, Bastos AADS, Búfalo JK, Tonuci LRDS. Baccharis dracunculifolia, uma das principais fontes vegetais da própolis brasileira. 1st ed. São Paulo: Unesp; 2012.

5. Ferronatto R, Marchesan E, Pezenti E, Bednarski F, Onofre SB. Antimicrobial activity of essential oils produced by Baccharis dracunculifolia D.C. and Baccharis uncinella D.C. (Asteraceae). Rev Bras Farmacogn. 2007 Apr/Jun;17:224-30. doi:10.1590/S0102-695X2007000200016. 
6. Barbosa LN, Probst IS, Andrade BF, Alves FC, Albano M, Cunha ML, et al. Fernandes-Júnior A. In vitro antibacterial and chemical properties of essential oils including native plants from Brazil against pathogenic and resistant bacteria. J. Oleo. Sci. 2015 Feb;64(3):289-98. doi:10.5650/jos.ess14209.

7. Parreira NA, Magalhães LG, Denis RM, Caixeta SC, Sousa JPB, Bastos JK. Antiprotozoal, schistosomicidal, and antimicrobial activities of the essential oil from the leaves of Baccharis dracunculifolia. Chem Biodivers. 2010 Apr;7(4):993-1001. doi:10.1002/cbdv.200900292.

8. Chaaban A, Martins CEN, Bretanhac LC, Mickec GA, Carrer AR, Rosab NF, et al. Insecticide activity of Baccharis dracunculifolia essential oil against Cochliomyia macellaria (Diptera: Calliphoridae). Nat Prod Res. 2017 Oct;32(24):2954-8. doi:10.1080/14786419.2017.1392947.

9. Florão A, Budel JM, Duarte MDR, Marcondes A, Rodrigues RAF, Rodrigues MVN, et al. Essential oils from Baccharis species (Asteraceae) have anti-inflammatory effects for human cells. J Essent Oil Res. 2012 Oct; 24(6):561-70. doi:10.1080/10412905.2012.728081.

10. Lage TCA, Montanari RM, Fernandes SA, Monteiro CMO, Senra TOS, Zeringota V, et al. Chemical composition and acaricidal activity of the essential oil of Baccharis dracunculifolia De Candole (1836) and its constituents nerolidol and limonene on larvae and engorged females of Rhipicephalus microplus (Acari: Ixodidae). Exp Parasitol. 2014 Oct;148(24):24-9. doi:10.1016/j.exppara.2014.10.011.

11. Búfalo MC, Candeias JMG, Sousa JPB, Bastos JK, Sforcin, JM. In vitro cytotoxic activity of Baccharis dracunculifolia and propolis against HEp-2 cells. Nat. Prod. Res. 2010 Oct;24:1710-8. doi: 10.1080/14786410902909300.

12. Verdi LG, Brighente IMC, Pizzolatti MG. Gênero Baccharis (Asteraceae): aspectos químicos, econômicos e biológicos. Quim Nova. 2005 Jan/Feb; 28(1):85-94. doi:10.1590/S0100-40422005000100017.

13. Frizzo CD, Atti-Serafini L, Laguna SE, Cassel E, Lorenzo D, Dellacassa E. Essential oil variability in Baccharis uncinella DC and Baccharis dracunculifolia DC growing wild in southern Brazil, Bolivia and Uruguay. Flavour Fragr J. 2008 Feb;23(2):99-106. doi:10.1002/ffj.1862.

14. Santos RF, Isobe MTC, Lalla JG, Haber LL, Marques MOM, Ming LC. Composição química e produtividade dos principais componentes do óleo essencial de Baccharis dracunculifolia DC. em função da adubação orgânica. Rev Bras Plantas Med. 2012;14:224-34.doi:10.1590/S1516-05722012000500017.

15. Salazar GJT, Sousa JP, Lima CNF, Lemosa ICS, Silva ARP, Freitas TS, et al. Phytochemical characterization of the Baccharis dracunculifolia DC (Asteraceae) essential oil and antibacterial activity evaluation. Ind Crop Prod. 2018 Sep;122:591-5. doi:10.1016/j.indcrop.2018.06.052.

16. Selani MM, Contreras-Castillo, CJ, Shirahigue LD, Gallo CR, Plata-Oviedo M. Montes-Villanueva ND. Wine industry residues extracts as natural antioxidants in raw and cooked chicken meat during frozen storage. Meat Sci. 2011 Jan;88(3):397-403. doi:10.1016/j.meatsci.2011.01.017.

17. Vaithiyanathan S, Naveena, BM, Muthukumar, M, Girish, PS, Kondaiah, N. Effect of dipping in pomegranate (Punica granatum) fruit juice phenolic solution on the shelf life of chicken meat under refrigerated storage $\left(4^{\circ} \mathrm{C}\right)$. Meat Sci. 2011 Jul;88(3):409-14. doi:10.1016/j.meatsci.2011.01.019.

18. Casagrande M, Zanela J, Júnior AW, Busso C, Wouk J, lurckevicz G, et al. Influence of time, temperature and solvent on the extraction of bioactive compounds of Baccharis dracunculifolia: In vitro antioxidant activity, antimicrobial potential, and phenolic compound quantification. Ind Crops Prod., 2018 Dec;125(1):207-19. doi:10.1016/j.indcrop.2018.08.088.

19. Arruda DC, D'alexandri FL, Katzin AM, Uliana SR. Antileishmanial activity of the terpene nerolidol. Antimicrob Agents Chemother. 2005 May; 49(5):1679-87. doi:10.1128/AAC.49.5.1679-1687.2005.

20. Ulubelen A, Topcu G, Eris C, Sonmez U, Kartal M, Kurucu S, Bozok-Johansson C. Terpenoids from Salvia sclarea. Phytochemistry. 1994 Jul;36(4):971-4. doi:10.1016/s0031-9422(00)90474-6.

21. Pacciaroni AV, Mongelli E, Espinar LA, Romano A, Ciccia G, Silva GL. Bioactive Constituents of Conyza albida. Planta Med. 2000 Dec;66(8):720-3. doi:10.1055/s-2000-9600.

22. Dajic-Stevanovic Z, Pljevljakusic D. Challenges and decision making in cultivation of medicinal and aromatic plants. 1st ed. Dordrecht: Springer; 2015. doi:10.1007/978-94-017-9810-5_8.

23. Figueiredo AC, Barroso JG, Pedro L, Scheffer JJC. Factors affecting secondary metabolite production in plants: volatile components and essential oils Factors affecting volatile and essential oil production in plants. Flavour Fragr J. 2008 May;23:213-26. doi:10.1002/ffj.1875.

24. Bano U, Khan AF, Mujeeb F, Mauryal N, Tabassum H, Siddiquil MH, et al. Effect of plant growth regulators on essential oil yield in aromatic plants. J Chem Pharm Res. 2016; 8(7):733-9.

25. Schonewald-Cox MC, Chambers B, Macbryde B, Thomas L. Genetics and conservation: a reference for managing wild animal and plant populations. 1st ed. Menlo Park: Benjamin Cummings Publishing Company; 1983.

26. Urbanska KM. Differentiation Patterns in Higher Plants. 1st ed. New York: Academic Press; 1987. 
27. Köppen, W. Grundriss der Klimakunde. 1st ed. Berlin: Walter de Gruyter; 1931.

28. Van Den Dool H, Kratz PD. A generalisation of the retention index system including linear temperature programmed gas-liquid chromatography. J Chromatogr. 1963;11:463-71.

29. Adams RP. Identification of essential oil components by gas chromatography/mass spectrometry. 4th ed. Carol Stream: Allured Publishing Corporation; 2007.

30. Brand-Williams W, Cuvelier ME, Berset C. Use of a free radical method to evaluate antioxidant activity. LWT Food Sci Technol. 1995;28:25-30. doi:10.1016/S0023-6438(95)80008-5.

31. Silva FAS, Azevedo CAV. The assistat software version 7.7 and its use in the analysis of experimental data. Af $J$ Agric Res. 2016 Sep;11(39):3733-40. doi:10.5897/AJAR2016.11522.

32. R Core Team. 2016. A language and environment for statistical computing. R Foundation for Statistical Computing, Vienna, Austria. Available online from: http://www.r-project.org/.

33. Martinez-Correa HA, Cabral FA, Magalhães PM, Queiroga CL, Godoy AT, Sánchez-Camargo AP, et al. Extracts from the leaves of Baccharis dracunculifolia obtained by a combination of extraction processes with supercritical CO2, ethanol and water. J. of Supercritical Fluids. 2012 Mar;63:31-9. doi:10.1016/j.supflu.2011.12.016.

34. Raven PH, Evert RF, Eichhorn SE. Biology of plants. 7th ed. New York: W.H. Freeman, 2005.

35. Souza JRP, Rocha JN, Morais H, Caramori PH, Laps J, Miranda LV. Development of holy-thorn under different light intensities and pruning levels. Hortic Bras. 2008 Feb;26(1):40-4.

36. Pegorini F, Maranhão LT, Rocha LD. Organização estrutural das folhas de Baccharis dracunculifolia DC., Asteraceae. Rev Bras Farm. 2008; 89:272-5. doi:10.1590/S1516-05722011000400011.

37. Liu H, Cao X, Liu X, Xin R, Wang J, Gao J, Wu B, et al. UV-B irradiation differentially regulates terpene synthases and terpene content of peach. Plant Cell Environ. 2017 Oct;40(10):2261-75. doi:10.1111/pce.13029.

38. Tiiva PT, Rinnan R, Faubert P, Räsänen J, Holopainen T, Kyrö E et al. Isoprene emission from a subarctic peatland under enhanced UV-B radiation.New Phytol. 2007; 176(2):346-55. doi:10.1111/j.1469-8137.2007.02164.x.

39. Vranová E, Coman D, Gruissem W. Network analysis of the MVA and MEP pathways for isoprenoid synthesis. Annu. Rev. Plant Biol. 2013; 64: 665-700. doi:10.1146/annurev-arplant-050312-120116.

40. Pazouki L, Niinemets Ü. Multi-substrate terpene synthases: their occurrence and physiological significance. Front. Plant Sci. 2016 Jul;7:1-16. doi:10.3389/fpls.2016.01019.

41. Lopes RC, Casali VWD, Barbosa LCA, Cecon PR. Different hydric influencing essential oil production from Plygonum punctatum Ell. Rev Bras Plantas Med. 2001;3(2):7-10.

42. Chai TT, Fadzillah NM, Kusnan M, Mahmood M. Water stress-induced oxidative damage and antioxidant responses in micropropagated banana plantlets. Biol Plant. 2005 Mar;49(1):153-6. doi:10.1007/s00000-005-31569.

43. Jeyaramrajaa PR, Meenakshi SN, Kumar RS, Joshi SD, Ramasubramanian B. Water deficit induced oxidative damage in tea (Camellia sinensis) plants. J Plant Physiol. 2005;162:413-9. doi:10.1016/j.jplph.2004.09.004.

44. Abdel-lateif KS, Eldeab HA, Maghrabi IA. The plant natural products: their antioxidants, free radical scavengers, DNA protection and antimicrobial activities. J Bioprocess Biotech. 2016; 6(9):2-7. doi:10.4172/2155-9821.1000293.

45. Chan WK, Tan L, Chan KG, Lee LH, Goh BH. Nerolidol: a sesquiterpene alcohol with multi-faceted pharmacological and biological activities. Molecules. 2016 May;21(5):1-40. doi:10.3390/molecules21050529.

46. Verma N, Shukla S. Impact of various factors responsible for fluctuation in plant secondary metabolites. J Appl Res Med Aromat Plants. 2015; 2(4):105-13. doi:10.1016/j.jarmap.2015.09.002.

47. Queiroga CL, Bastos JK, De Sousa JPB, Magalhães PM. Comparison of the Chemical Composition of the Essential Oil and the Water Soluble Oil of Baccharis dracunculifolia DC. (Asteraceae). J Essent Oil Res. 2011 Dec;20(2):1114. doi:10.1080/10412905.2008.9699967.

48. Pereira CB, Farago PV, Borsato DM, Folquitto DG, Maia BHLNS, Esmerino LA, et al. Chemical Composition and Biological Activities of Baccharis milleflora Essential Oil. Lat. Am. J. Pharm. 2016, 35:2225-33.

49. Besten MA, Nunes DS, Júnior AW, Sens SL, Granato D, Simionatto EL,et al. Chemical composition of volatiles from male and female specimens of Baccharis trimera collected in two distant regions of southern Brazil: a comparative study using chemometrics. Quim Nova. 2013;36(8):1096-100. doi:10.1590/S010040422013000800003.

50. Silva FG, Oliveira CBA, Pinto JEBP, Nascimento VE, Santos S, Seraphind JC, et al. Seasonal Variability in the Essential Oils of Wild and Cultivated Baccharis trimera. J Braz Chem Soc. 2007; 18(5):990-7. doi:10.1590/S010350532007000500017.

51. Ahmad P, Sarwat M, Sharma S. Reactive oxygen species, antioxidants and signaling in plants. J Plant Biol. 2008; 51:167-73. doi:10.1007/BF03030694.

52. Taiz L, Zeiger E. Plant Physiology. 5th ed. Sunderland: Sinauer Associates Inc.; 2013. 
53. Neto JDN, Almeida AAC, Oliveira JS, Santos PS, Sousa DP, Freitas RM. Antioxidant effects of nerolidol in mice hippocampus after open field test. Neurochem Res. 2013 Sep;38(9):1861-70. doi:10.1007/s11064-013-1092-2.

54. Dorman HD, Figueiredo AC, Barroso JG, Deans SG. In vitro evaluation of antioxidant activity of essential oils and their components. Flavour and Fragr J: 2000;15(1):12-6. doi: 10.1002/(SICI)1099-1026(200001/02)15:1<12::AIDFFJ858>3.0.CO;2-V

55. Yu L, Yan J, Sun Z. D-limonene exhibits anti-inflammatory and antioxidant properties in an ulcerative colitis rat model via regulation of iNOS, COX-2, PGE2 and ERK signaling pathways. Mol Med Rep. 2017; 15(4):2339-46. doi: 10.3892/mmr.2017.6241.

56. Miranda CASF, Maria das Graças Cardoso MGC, Batista LR, Rodrigues LMA, Figueiredo ACS. Essential oils from leaves of various species: antioxidant and antibacterial properties on growth in pathogenic species. Rev. Ciênc. Agron. 2016 Jan-Mar,47:213-20.

57. Ruberto G, Baratta MT. Antioxidant activity of selected essential oil components in two lipid model systems. Food Chem. 2000 May;69(2):167-74. doi:10.1016/S0308-8146(99)00247-2.

58. Silva ER, Lazarotto DC, Pawlowski A, Schwambach J, Soares GLG. Antioxidant evaluation of Baccharis patens and Baccharis psiadioides essential oils. J. Essent. Oil-Bear. Plants, 2018 May;21:485-92. doi: 10.1080/0972060X.2018.1470944.

59. Xavier MN, Alves JM, Carneiro NS, Souchie EL, Silva EAJ, Martins CHG, et al. Chemical composition from essential oil of Cardiopetalum calophyllum Schltdl. (Annonaceae) and their antioxidant, antibacterial and antifungal activities. Rev Virt Quim. 2016 Jul; 8(5):1433-48. doi:10.21577/1984-6835.20160101.

60. Bittencourt MLF, Ribeiro PRb, Franco RLP, Hilhorst HWM, Castro RD, Fernandez LG. Metabolite profiling, antioxidant and antibacterial activities of Brazilian propolis: Use of correlation and multivariate analyses to identify potential bioactive compounds. Food Res Int. 2015,76(3):449-57. doi:10.1016/j.foodres.2015.07.008.

61. Taarit MB, Msaada K, Hosni K, Hammami M, Kchouk ME, Marzouk, B. Plant growth, essential oil yield and composition of sage (Salvia officinalis L.) fruits cultivated under salt stress conditions. Ind. Crops Prod. 2009 Oct; 30(3):333-7. doi:10.1016/j.indcrop.2009.06.001.

62. Ghasemi M, Babaeian Jelodar N, Modarresi M, Bagheri N, Jamali A. Increase of Chamazulene and $\alpha$-Bisabolol contents of the essential oil of german chamomile (Matricaria chamomilla L.) using salicylic acid treatments under normal and heat stress conditions. Foods. 2016 Sep;5(3):1-14. doi:10.3390/foods5030056.

63. Lemoine NP, Burkepile DE, Parker JD. Variable effects of temperature on insect herbivory. Peer J. 2014 May;2:e376. doi:10.7717/peerj.376.

64. Chan WK, Tan LTH, Chan KG, Lee LH, Goh BH. Nerolidol: a sesquiterpene alcohol with multi-faceted pharmacological and biological activities. Molecules. 2016 May;21(5):1-40. doi:10.3390/molecules21050529.

2021 by the authors. Submitted for possible open access publication under the terms and conditions of the Creative Commons Attribution (CC BY NC) license (https://creativecommons.org/licenses/by-nc/4.0/). 